\title{
PENGARUHI PENGEMBANGAN KARIR TERHADAP KEPUASAN KERJA PADA PT. ARTA BOGA CEMERLANG MEDAN
}

\author{
Ester Hervina Sihombing \\ Politeknik Unggul LP3M Medan \\ J1.Iskandar Muda No.3 EF Medan-Sumatera Utara \\ www.politeknikunggul.ac.id, info@politeknikunggul.ac.id, \\ esterhervinasihombing@gmail.com
}

\begin{abstract}
Absctract
Organizational culture and the Dissemination System Faith And Values Evolving hearts An organization as well as directing Behavior And anggotaanggotanya.Budaya organization and can be competitive edge yangutama Become instrument, ie If the organizational culture and support the development of organizational strategy and

Cultural organizations and besides influential organizations and boarding costs Against, Against Also influential employee satisfaction. The High employee satisfaction is a prayer One indicator of the effectiveness of management Also, Which Means that the culture of the organization and has managed WITH Good

Results The results showed that job satisfaction of employees Very Small is influenced by factors as well as the organizational culture in which HAL singer can be seen from $R^{2}$ value of 0.317 That gives meaning that employee job satisfaction is influenced by factors Organizational Culture Only $31.70 \%$

Searching Google Articles Seeing his little influence organizational culture and So should ADA action Yang in doing so that the organizational culture as well as the singer can be MORE in FIX implementation because of the impact The Very Small For Companies hearts give satisfaction shown to employees

Keywords: Organizational Culture, Employee Satisfaction
\end{abstract}




\section{PENDAHULUAN}

\subsection{Latar Belakang Masalah}

Pada dasarnya setiap karyawan bekerja dalam sebuah organisasi/ perusahaan membawa nilai dan motivasi masing-masing yang berbeda, Adapun salah satu motivasi yang membentuk keinginan dan ambisi mereka untuk mencapai kesuksesan dalam bekerja adalah karir. Pengembangan karir karyawan dalam hal ini merupakan kewajiban perusahaan untuk menyiapkannya bagi karyawankaryawan yang berprestasi, namun demikian karir tidaklah menjadi tanggung jawab bagi perusahaan untuk dapat dicapai oleh karyawan karena pencapaian karir tertinggi karyawan sepenuhnya merupakan tanggung jawab mereka secara individu.

$$
\text { Bagi perusahaan tujuan }
$$

dilakukannya perencanaan terhadap pengembangan karir karyawan untuk mendapatkan kontribusi karyawan terhadap perusahaan secara maksimal melalui potensi yang di milikinya. Melalui pemberian kesempatan kepada karyawan untuk berkembang apakah dengan meningkatkan keterampilan dan kemampuannya atau dengan memberi kesempatan untuk memperoleh pendidikan yang lebih baik dari sebelumnya. Hal ini di lakukan perusahaan dalam usaha untuk pengembangan karir bagi karyawan.
Dengan pengembangan karir tersebut di harapkan perusahaan mampu menciptakan kepuasan kerja yang tinggi di dalam diri karyawan. Untuk itu perlu di ketahui faktor-faktor yang secara langsung dianggap berpengaruh dalam memberikan kepuasan kepada karyawan. Adapun faktorfaktor tersebut secara umum dapat di lihat pada aspek-aspek yang berhubungan dengan kondisi kerja, berhubungan dengan teman sekerja, dengan pengawasan.

Setelah di ketahui apa saja yang menjadi faktor kepuasan karyawan maka di harapkan akan membentuk sikap yang lebih positif dan pada akhirnya di harapkan produktivitas dan kinerja akan meningkat . PT. ARTA BOGA CERMERLANG MEDAN dalam mengembangkan karir karyawannya saat ini telah menggunakan komponen-komponen pengembangan karyawan yang mengadopsi dari kepentingan karyawan maupun organisasi

Adapun untuk jumlah data karyawan pada PT. ARTA BOGA CERMERLANG MEDAN 2014-2015 adalah sebagai berikut: 


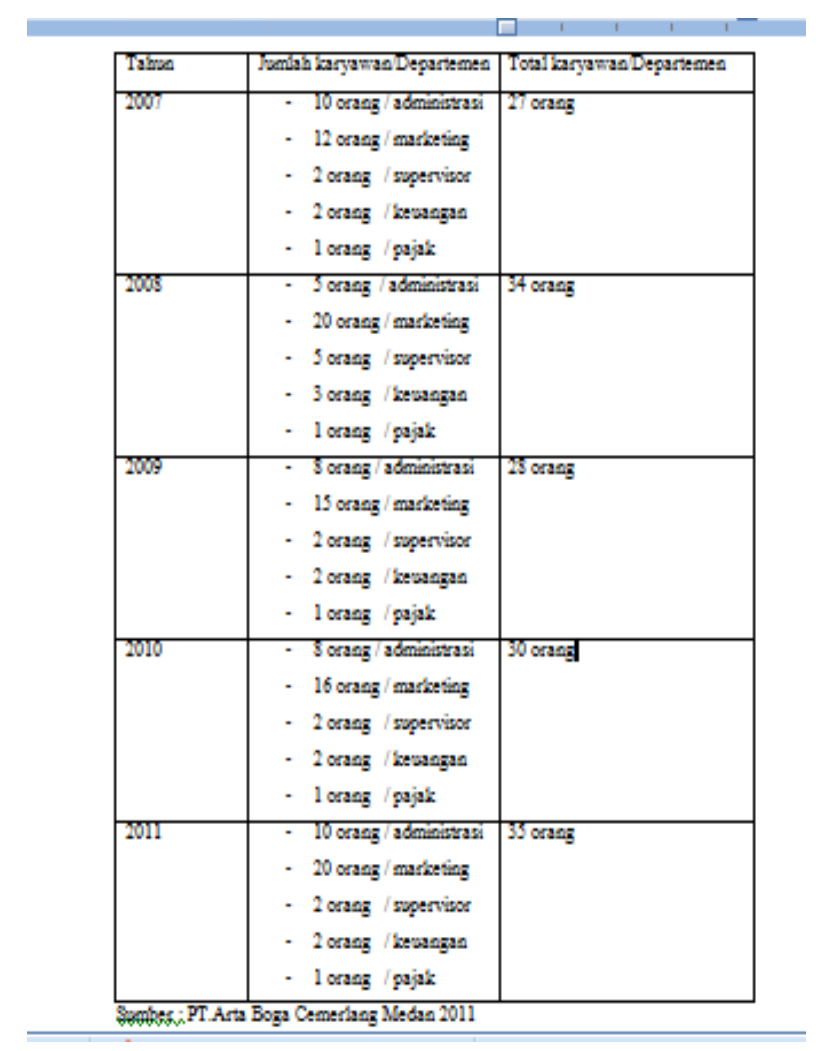

Sumber : PT. Arta Boga Cemerlang Medan 2011

Dari data tersebut menjelaskan bahwa untuk jumlah karyawan selama 5 tahun pada dasarnya di sesuaikan untuk kepentingan organisasi maupun pekerjaaan yang ada, namun demikian data tersebut memperlihat bahwa jumlah karyawan setiap tahunnya mengalami fluktuasi, ini menunjukkan masih banyak karyawan yang tidak puas bekerja sehingga menimbulkan tingkat turn over karyawan.
Adapun untuk data LTO (labour turn over ) sbb.

\begin{tabular}{|l|l|l|l|}
\hline Tahun & $\begin{array}{l}\text { Jumlah } \\
\text { pegawai } \\
\text { masuk }\end{array}$ & $\begin{array}{l}\text { Jumlah } \\
\text { Pegawai } \\
\text { keluar }\end{array}$ & $\begin{array}{l}\text { Turn } \\
\text { Over }\end{array}$ \\
\hline 2008 & 13 & 15 & $3.0 \%$ \\
\hline 2009 & 12 & 17 & $7.6 \%$ \\
\hline 2010 & 11 & 16 & $4.6 \%$ \\
\hline 2011 & 13 & 10 & $7.6 \%$ \\
\hline 2012 & 11 & 16 & $8.3 \%$ \\
\hline
\end{tabular}

Data turn over yang terdapat pada tabel turn over tersebut diatas dapat di hitung persentasenya dengan menggunakan rumus LTO ( Hasibuan 2003:52) ;

Labour Turn Over $\underline{\sum(\text { yang keluar }- \text { yang di terima }) \text { X } 100 \%}$

Jadi hasil perhitungannya sebagai berikut :

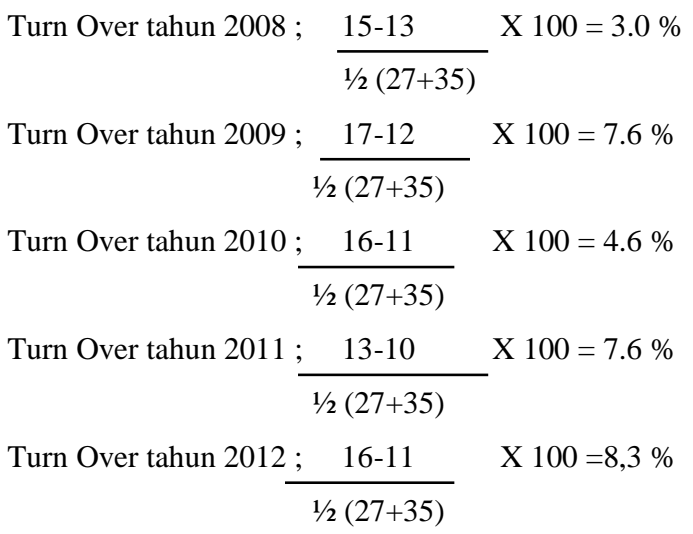

Demikian kondisi di atas menunjukkan penempatan karyawan dan pengembangan karir mereka masih belum menerapkan cara-cara yang tersistematis seperti misalnya menggunakan metode Analisa jabatan atau Sistem informasi Sumber Daya Manusia (SISDM) yang 
mengakibatkan banyak karyawan yang merasa tidak puas akibat ketidakjelasan karir mereka sebagai pekerja. Hal ini karena pengembangan karir seseorang juga merupakan salah satu bentuk apresiasi perusahaan terhadap kinerja yang di tunjukkan oleh seorang karyawan. Aspek ini juga merupakan suatu pemicu yang juga di rasakan dapat menimbulkan kepuasan terhadap karyawan selama menjalankan pekerjaannya.untuk itu perusahaan harus berupaya mencari tahu pada aspek apa saja seorang karyawan harus eksplorasi potensi dan bakatnya untuk di kembangkan sehingga dapat menjadi dasar bagi pengembangan karir karyawan.

Mempertimbangkan hal ini penulis berpendapat bahwa pegembangan karir termasuk komponen pembentuk kepuasan kerja. Adapun yang melatarbelakangi pemikiran tersebut dikarenakan pengembangan karir yang jelas dapat mengakibatkan seorang karyawan menjadi lebih nyaman dalam menjalankan pekerjaannya di perusahaan di mana hal ini dapat mengakibatkan tingkat kepuasan yang sangat baik

Oleh sebab itu, maka penelitian ini mengangkat judul " Pengaruh pengembangan karir terhadap kepuasan kerja pada PT. Arta Boga Cemerlang.

\section{TINJAUAN PUSTAKA}

\subsection{KEPUASAN KERJA}

Menurut Panggabean

(2005)

pengembangan karier adalah semua usaha pribadi karyawan yang ditujukan untuk melaksanakan rencana kariernya melalui pendidikan, pelatihan, pencarian dan perolehan kerja dan pengalaman kerja.

Definisi lain yang menjelaskan tentang kepuasan kerja Robbins (2005 : 122) menyatakan bahwa istilah kepuasan kerja merujuk kepada sikap umum seorang individu kepada pekerjaannya. Seseorang dengan tingkat kepuasan tinggi menunjukkan sikap positif terhadap kerjanya: sementara seseorang yang tidak puas menunjukkan sikap negatif terhadap kerjanya.Dalam bukunya Gitosudarmo dan Sudita (2006 ; 90) menuliskan teori Dua Faktor Herzberg yang berkaitan dengan kepuasan kerja yang sering dipakai pada saat ini ada pada Teori Dua Faktor (Motivator Hygene Theory). Herzberg mengemukakan bahwa pekerja dalam melaksanakan pekerjaannya dipengaruhi oleh dua faktor utama yang merupakan kebutuhan, yaitu:

1. Faktor motivasi yang menyangkut kebutuhan psikologis yang berhubungan dengan penghargaan terhadap individu yang secara langsung berkaitan dengan pekerjaannya (elemen pekerjaan itu sendiri) dan merupakan sumber kepuasan kerja. Faktor-faktor tersebut mencakup: 
a. Pekerjaan itu sendiri (The work itself) Menyangkut karakteristik dari pekerjaan, yaitu apakah pekerjaan tersebut menantang, menarik ataukah justru membosankan.

b. Prestasi kerja (Achievement) Adanya kesempatan untuk menunjukkan prestasi yang lebih baik darisebelumnya, yang diperoleh melalui usaha dan kemampuan.

c. Promosi (Promotion)Tersedianya kesempatan untuk berkembang dalam pekerjaan dan jabatan.

d. Pengakuan (Recognition) Adalah adanya penghargaan dan pengakuan atas prestasi kerja melalui umpan balik yang diterima.

e. Tanggung Jawab (Reponsibility) Tanggung jawab disini adalah kewajiban menjalankan fungsi jabatan dan tugas yang sesuai dengan kemampuannya serta pengarahan yang diterima.

2. Faktor-faktor pemeliharaan (maintenance factors) atau dikenal juga dengan hygene factors atau dissatisfier. Merupakan faktor-faktor yang berhubungan ketidakpuasan kerja dan merupakan suatu faktor ekstrinsik, yang berkaitan dengan keadaan pekerjaan. Faktor-faktor ini mencakup:

a. Rekan Kerja (co worker) yang dimaksud adalah apakah dalam bekerja rekan-rekan dapat diajak bekerjasama, memiliki kompetensi, bersahabat, dan saling tolongmenolong.

b. Gaya penyeliaan (quality and technical support) Gaya penyeliaan yang dimaksud disini adalah kualitas dan bentukpengawasan, pengarahan dan pembimbingan yang diterima dari atasan.

c. Hubungan antar karyawan (Relations with others) Adanya kerja sama antar bawahan dan atasan dalm hal tolong menolong dan saling memberikan dorongan.

d. Kondisi lingkungan fisik kerja (psychological working conditions) Meliputi kondisi lingkungan baik tempat bekerja, seperti penerangan, tempratur, kualitas udara, serta peralatan kerja.

e. Kebijaksanaan perusahaan (Company policies) Termasuk di dalamnya mengenai administrasi, dan prosedur kerja yang diterapkan perusahaan, peraturan-peraturan kebijaksanaan perusahaan, dan tindakan yang diambil perusahaan untuk kepentingan karyawan.

f. Gaji (Salary pay) Yang dimaksud adalah imbalan jasa berupa uang yang dibawa oleh karyawan sesuai dengan jenis dan beban pekerjaan yang dilaksanakan.

g. Keamanan kerja (Job security) Berupa kejelasan dari pekerjaan yang 
dipegang, kelangsungan pekerjaan, jaminan hari tua, tunjangan-tunjangan, tingkat kepangkatan,serta kedudukan dalam organisasi.

\subsection{PENGEMBANGAN KARIR}

Pada dasarnya, pengembangan karir dapat dijelaskan dari dua perspektif, yaitu internal dan eksternal. Secara eksternal, pengembangan karir dapat dipandang sebagai suatu pendekatan formal yang diambil organisasi guna memastikan bahwa orang-orang dengan kualifikasi pengalaman yang tepat tersedia pada saat dibutuhkan (dalam Simamora, 2005 : 34). Menurut Rivai dan Sagala (2009 : 28) pengembangan karir adalah proses peningkatan kemampuan kerja individu yang dicapai dalam rangka mencapai karir yang diinginkan.Dapat disimpulkan suatu pemahaman bahwa pengembangan karir adalah suatu proses berkesinambungan yang dilalui individu melalui upaya-upaya pribadi dalam rangka mewujudkan tujuan perencanaan karirnya yang disesuaikan dengan kondisi organisasi.

\section{Tahap - Tahap Pengembangan Karir}

Dessler (2005: 78) mengemukakan adanya tahap-tahap pengembangan karir yang dilalui individu dalam kehidupan kerjanya, yaitu :

\section{Tahap penjelajahan}

Tahap ini terjadi pada periode usia 15 - 24 tahun. Individu secara serius menjelajahi berbagai alternatif

kedudukan, berusaha untuk mencocokkan alternatifalternatif ini dengan minat dan kemampuannya, serta mencoba memulai suatu pekerjaan.

2. Tahap penetapan

a. Sub tahap percobaan

Tahap ini berlangsung pada usia $25-30$ tahun. Individu menetapkan bidang pilihan yang cocok, dan jika tidak cocok berusaha mengubahnya.

b. Sub tahap pemantapan

Tahap ini berlangsung pada usia 30

- 40. Selama periode ini, tujuan kedudukan perusahaan ditetapkan dan perencanaan karir yang lebih eksklusif dijalankan untuk menetapkan urutan bagi pemenuhan tujuantujuan tersebut.

c. Sub tahap krisis pertengahan karir Tahap ini berlangsung pada usia 40an. Selama periode ini orang sering membuat penilaian baru yang besar atas kemajuan mereka sehubungan dengan ambisi dan tujuan awal karir mereka.

3. Tahap pemeliharaan Tahap ini terjadi pada periode usia 40-65 tahun. Pada periode ini, individu memelihara tujuannya dalam dunia kerja. 
4. Tahap kemerosotan

Tahap ini disebut juga usia pensiun, di mana individu menghadapi prospek harus menerima berkurangnya level kekuasaan dan tanggung jawab.

\section{Tomponen-komponen pengembangan}

\section{karir}

Menurut Rivai dan Sagala (2009 :

33) aspek-aspek yang terdapat dalam pengembangan karir individu adalah:

\section{Prestasi kerja (Job Performance)}

Merupakan komponen yang paling penting untuk pengembangan karir yang paling penting untuk meningkatkan dan mengembangkan karir seorang karyawan. Kemajuan karir sebagian besar tergantung atas prestasi kerja yang baik dan etis. Dengan mengetahui hasil atas kinerjanya maka karyawan dapat mengukur kesempatannya terhadap pengembangan karir. Asumsi terhadap kinerja yang baik akan melandasi seluruh aktivitas pengembangan karir. Ketika kinerja di bawah standar maka dengan mengabaikan upaya-upaya ke arah pengembangan karir pun biasanya tujuan karir yang paling sederhana pun tidak dapat dicapai. Kemajuan karir umumnya terletak pada kinerja dan prestasi

2. Pengenalan oleh pihak lain (Exposure)

Tanpa pengenalan oleh pihak lain maka karyawan yang baik tidak akan mendapatkan peluang yang diperlukan guna mencapai tujuan mereka. Manajer atau atasan memperoleh pengenalan ini terutama melalui kinerja, dan prestasi karyawan, laporantertulis, presentasi lisan, pekerjaan komite dan jam-jam yang dihabiskan.

3. Jaringan kerja (Net working)

Jaringan kerja berarti perolehan eksposure di luar perusahaan. Mencakup kontak pribadi dan professional. Jaringan tersebut akan sangat bermanfaat bagi karyawan terutama dalam pengembangan karirnya.

4. Pengunduran diri (resignation)

Kesempatan berkarier yang banyak dalam sebuah perusahaan memberikan kesempatanuntuk pengembangan karir karyawan, hal ini akan mengurangi tingkat pengunduran diri untuk mengembangkan diri di perusahaan lain (leveraging).

5. Kesetiaan terhadap organisasi (Organization loyalty)

Level loyalitas yang rendah merupakan hal yang umum terjadi di kalangan lulusan perguruan tinggi terkini yang disebabkan ekspektasi terlalu tinggi pada perusahaan tempatnya bekerja pertama kali sehingga seringkali menimbulkan kekecewaan. Hal yang sama juga terjadi pada kelompok profesional dimana loyalitas pertamannya diperuntukkan bagi profesi. Untuk mengatasi hal ini sekaligus mengurangi 
tingkat keluarnya karyawan (turn over) biasanya perusahaan "membeli" loyalitas karyawan dengan gaji, tunjangan yang tinggi, melakukan praktek-praktek SDM yang efektif seperti perencanaan dan pengembangan karir. Sementara perusahaan lainnya membatasi mobilitas dengan mengikat kontrak nonkompetitif untuk menghambat karyawan bekerja di perusahaan pesaing, biasanya kontrak ini berlaku untuk jangka waktu setahun.

6. Pembimbing dan sponsor (Mentors and sponsors)

Adanya pembimbing dan sponsor akan membantu karyawan dalam mengembangkan karirnya. Pembimbing akan memberikan nasehat-nasehat atau saran-saran kepada karyawan dalam upaya pengembangan karirnya, pembimbing berasal dari internal perusahaan. Mentor adalah seseorang di dalam perusahaan yang menciptakan kesempatan untuk pengembangan karirnya.

7. Bawahan yang mempunyai peran kunci (Key subordinate)

Atasan yang berhasil memiliki bawahan yang membantu kinerja mereka. Bawahan dapat memiliki pengetahuan dan keterampilan khusus sehingga atasan dapat belajar darinya, serta membantu atasan melakukan tugas-tugasnya. Bawahan kunci mengumpulkan, menafsirkan informasi, melengkapi keterampilan atasan mereka dan bekerja secara kooperatif untuk mengembangkan karir atasan mereka. Hal ini juga menguntungkan bagi mereka membuat mereka mendaki tangga karir ketika atasan mereka dipromosikan, serta menerima tugas penting dalam upaya mengembangkan karir mereka.

8. Peluang untuk tumbuh (Growth opportunities)

Karyawan hendaknya diberikan kesempatan untuk meningkatkan kemampuannya, misalnya melalui pelatihan-pelatihan, kursus, dan melanjutkan pendidikannya. Hal ini akan memberikan karyawan kesempatan untuk tumbuh dan berkembang sesuai dengan rencana karirnya.

9. Pengalaman internasional (International experience)

Untuk orang-orang yang mendekati posisi operasional atau staf senior, maka pengalaman internasional menjadi peluang pertumbuhan yang sangat penting. Khususnya bagi perusahaan-perusahaan domestik dimana penjualan tinggi berasal dari operasi internasional, juga bagi perusahaan-perusahaan global. Penelitian ini menggunakan komponen pengembangan karir milik Rivai dan Sagala (2009 : 35) dimana pernyataan-pernyataan disusun untuk mengukur apakah perusahaan telah menciptakan kondisi yang menunjang upaya-upaya individu untuk mewujudkan perencanaan karirnya, di mana di dalamnya juga mencakup upaya 
perusahaan dalam menciptakan kesadaran individu akan pentingnya mengetahui sasaran karir, serta langkah-langkah yang perlu diketahui oleh individu karyawan untuk mencapai sasaran karir tersebut.

Namun komponen bawahan yang mempunyai peran kunci (key subordinate) tidak dipergunakan, karena hubungan antara atasan dan bawahan sudah terwakili oleh aspek loyalitas organisasi serta aspek pembimbing dan sponsor.

\section{HASIL PENELITIAN DAN PEMBAHASAN}

\section{Pengujian Validitas dan Reliabilitas}

a. Uji Validitas

Validitas adalah suatu tingkatan di mana skala atau seperangkat ukuran merepresentasikan konsep secara akurat. Validitas meninjau seberapa baik status konsep di definisikan oleh variabek pengukuran yang di pergunakan. Suatu instrument di katakana valid jika mampu mengukur apa yang seharusnya di ukur dan mampu mengungkapkan data dari variable yang di teliti secara tepat. Pada penelitian ini uji validitas di lakukan dengan menggunakan Correlation Bivariat antara masing-masing skor indicator dengan total skor konstruk yaitu nilai korelasi Pearson.

Tabel 3.1 Validitas Pengembangan karir

\begin{tabular}{|l|l|l|l|}
\hline $\begin{array}{l}\text { Variabel } \\
\text { Penelitian }\end{array}$ & Item & $\begin{array}{l}\text { Koefi } \\
\text { sien } \\
\text { Korel } \\
\text { asi }\end{array}$ & $\begin{array}{l}\text { Keterang } \\
\text { an }\end{array}$ \\
\hline $\begin{array}{l}\text { Pengembang } \\
\text { an karir }\end{array}$ & $\mathrm{X} 1.1$ & .728 & Valid \\
\hline & $\mathrm{X} 1.2$ & .671 & Valid \\
\hline & $\mathrm{X} 1.3$ & .617 & Valid \\
\hline & $\mathrm{X} 1.4$ & .549 & Valid \\
\hline & $\mathrm{X} 1.5$ & .632 & Valid \\
\hline & $\mathrm{X} 1.6$ & .603 & Valid \\
\hline
\end{tabular}

Tabel 3.2 Validitas Kepuasan Kerja Karyawan

\begin{tabular}{|c|c|c|c|}
\hline $\begin{array}{l}\text { Variabel } \\
\text { Penelitia } \\
\text { n }\end{array}$ & Item & $\begin{array}{l}\text { Koefisie } \\
\mathrm{n} \\
\text { Korelasi }\end{array}$ & $\begin{array}{l}\text { Keteranga } \\
\mathrm{n}\end{array}$ \\
\hline \multirow[t]{7}{*}{$\begin{array}{l}\text { Kepuasa } \\
\text { n } \\
\text { Karyawa } \\
\text { n }\end{array}$} & $\begin{array}{l}\text { Y1. } \\
1\end{array}$ & .572 & Valid \\
\hline & $\begin{array}{l}\text { Y1. } \\
2\end{array}$ & .643 & Valid \\
\hline & $\begin{array}{l}\text { Y1. } \\
3\end{array}$ & .601 & Valid \\
\hline & $\begin{array}{l}\text { Y1. } \\
4\end{array}$ & .436 & Valid \\
\hline & $\begin{array}{l}\text { Y1. } \\
5\end{array}$ & .353 & Valid \\
\hline & $\begin{array}{l}\text { Y1. } \\
6\end{array}$ & .386 & Valid \\
\hline & $\begin{array}{l}\text { Y1. } \\
7\end{array}$ & .632 & Valid \\
\hline
\end{tabular}




\begin{tabular}{|l|l|l|l|}
\hline & $\begin{array}{l}\text { Y1. } \\
8\end{array}$ & .619 & Valid \\
\hline & $\begin{array}{l}\text { Y1. } \\
9\end{array}$ & .577 & Valid \\
\hline
\end{tabular}

Uji Reabilitas

Reabilitas merujuk sejauh mana skala mampu menciptakan hasil yang konsisten jika pengukuran berulang dilakukan. Realibilitas merupakan alat untuk mengukur suatu kuesioner yang merupakan indikator dari variabel.relibilitas diperlihatkan oleh nilai yang menunjukkan kekonsistenan data hasil penelitian yang nilainya bervariasi mulai dari 0 sampai 1 . Suatu variabel atau konstruk dikatakan reliable jika memberikan nilai Cronbach Alpha > 0,60 (Ghozali, 2005 : 42). Hasil pengujian yang telah dilakukan dapat dilihat pada table 5.5 di bawa.

Tabel 3.3 Hasil Pengujian Reliabilitas

\begin{tabular}{|c|c|c|}
\hline Variabel & $\begin{array}{l}\text { Cronbac } \\
\text { h Alpha }\end{array}$ & $\begin{array}{l}\text { Keterenga } \\
n\end{array}$ \\
\hline $\begin{array}{l}\text { Pengembanga } \\
\text { n karir }\end{array}$ & 0.686 & Reliabel \\
\hline $\begin{array}{l}\text { Kepuasan } \\
\text { karyawan }\end{array}$ & 0.687 & Reliabel \\
\hline
\end{tabular}

Selain itu juga di uji dengan statistik kosmogorov-smirnov di mana hasil pengujian ini di peroleh nilai P-value Asymp.Sig) sebesar $>0.10$ sehingga dapat di simpulkan nilai residual mengikuti distribusi normal.Adapun hasil pengujian dapat di lihat pada tabel 5.11

Tabel 3.4 Kolmogorov - Sriminov Test

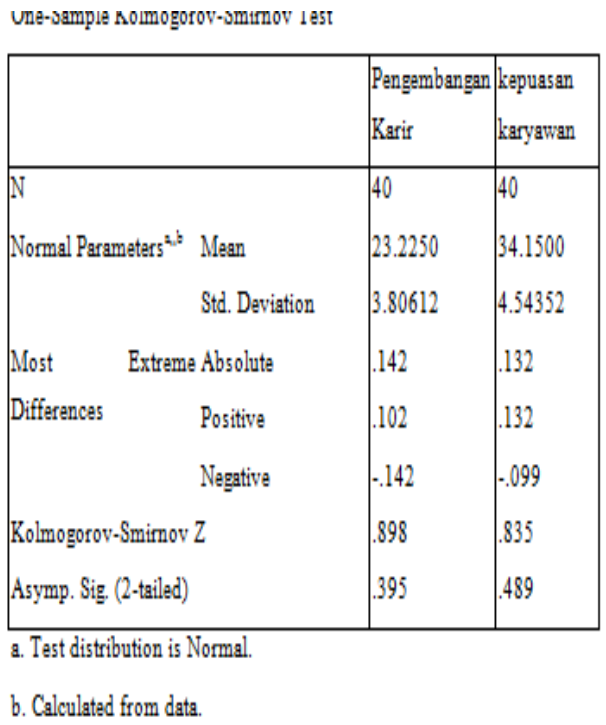

\section{Normalitas data}

Pengujian normalitas data untuk melihat apakah dalam model regresi, variable dependen dan variable independennya memiliki distribusi normal atau tidak.Model yang paling baik hádala distribuís data normal atu mendekati normal.

Ketentuannya jika data menyebar di sekitar garis diagonal dan mengikutu arah garis diagonal, maka model regresi memenuhi asumís normalitas . Jika data 
menyebar jauh dari garis diagonal atau tidak mengikuti arah garis diagonal maka model regresi tidak memenuhi asumsi normalitas Santoso 2000)

\section{Gambar 3.5 Scater Plot}

\section{Normal P-P Plot of Regression Standardized Residual}

Dependent Variable: Kepuasan kerja

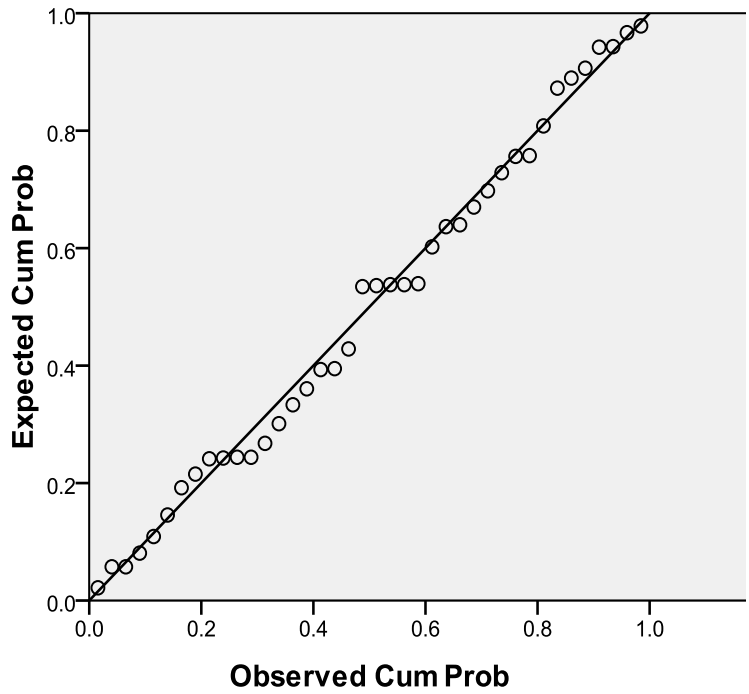

Melihat gambar diatas, data-data terlihat cenderung mengikuti garis diagonal, sehingga data dalam penelitian ini tergolong normal. Dengan demikian data dalam penelitian ini layak untuk di uji dengan regresi linier

\section{Pegujian Hipotesis}

Untuk membuktikan hipotesis maka dapat di perhatikan koefisien regresi berdasarkan jasil perhitngan dengan menggunakan SPSS maka hasil yang di peroleh dapat di lihat pada tabel 3.6

\section{Tabel 3.6 tabel Output Regressi}

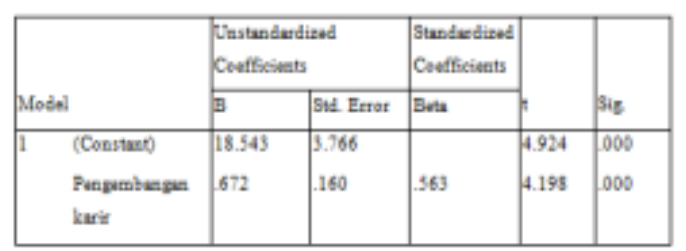

Berdasarkan tabel di atas model tersebut dapat di formulasikan sebagai berikut:

$$
\mathrm{Y}=18.543+0.672
$$

- Nilai Konstanta sebesar 18.543 menjelaskan bahwa apabila pengembangan karir dalam keadaan konstan (tetap ) maka menyebabkan kepuasan karyawan sebesar 18.54 $\%$

- Koefesien regresi dari variable pengembangan karyawan adalah sebesar 0.672 menjelaskan bahwa pada setiap perbaikan aspek Budaya Organisasi maka akan menentukan tingkat Kepuasan Kerja Karyawan yang ada sebesar $67.2 \%$

\section{6 Koefisien Determinasi}

Koefisien determinasi adalah suatu koefisien yang menunjukkan besarnya kontribusi variabel bebas di dalam 
mempengaruhi perubahan (variasi) naik turunnya variabel terikatnya.

\section{Tabel 3.7 Koefisien Determinasi}

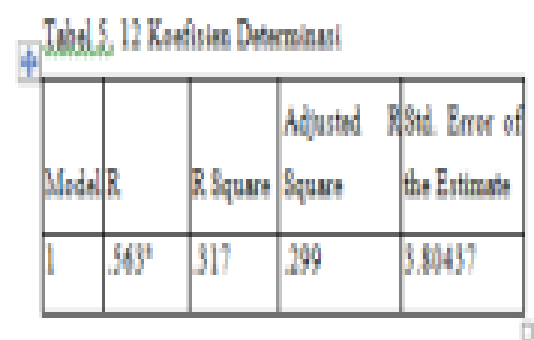

Dari hasil perhitungan koefisien determinasi menunjukkan bahwa pengaruh variabel Pengembangan karir terhadap variabel terikat yaitu Kepuasan karyawan relatif Rendah. Nilai koefisien determinasi yang dinyatakan oleh $R$ Square $\left(\mathrm{R}^{2}\right)$ dari variabel bebas tersebut adalah 0.317. Nilai $\mathrm{R}^{2}$ sebesar 0.317 memberikan makna bahwa Kepuasan Kerja karyawan di pengaruhi oleh faktor Pengembangan karir adalah sebesar $31.7 \%$ sisanya sebesar 68.3 $\%$ adalah di pengaruhi oleh variabelvariabel lain di luar dari variabel yang telah di teliti. Dalam hal ini dapat di jelaskan melalui tabel.5.12

\section{Pembahasan Hasil}

\subsection{Pengaruh Pengembangan karir} terhadap Kepuasan Kerja Karyawan

Berdasarkan hasil pengolahan data bahwa pengaruh pengembangan karir terhadap kepuasan kerja karyawan pada PT. ARTA BOGA CERMERLANG MEDAN mempunyai pengaruh sebesar 0.672 (67.2\%) yang berarti jika pengembangan karir berlangsung konstan (tetap) maka pengaruh pengembangan karir tersebut berdampak positif dan signifikann (bermakna )terhadap kepuasan kerja karyawan.

\section{KESIMPULAN DAN SARAN}

\section{Kesimpulan}

Hasil penelitian menunjukkan bahwasanya kepuasan kerja karyawan sangat kecil di pengaruhi oleh faktor Pengembangan Karir di mana hal ini dapat di lihat dari nilai $\mathrm{R}^{2}$ sebesar 0.317 yang memberikan makna bahwa Kepuasan Kerja karyawan di pengaruhi oleh faktor Pengembangan karirhanya $31.70 \%$ selebihnya lebih banyak faktor lain yang tidak di teliti dalam penelitian ini yang memberikan pengaruh terhadap kepuasan karyawan

\section{Saran}

Perusahaan harus secara serius memperbaiki pengembangan karir dalam perusahaan karena pengembangan karir yang ada saat ini sangat tidak efektif,mengingat sangat lemahnya pengaruh terhadap kepuasan karyawan.Perusahaan juga harus segera melakukan evaluasi apa saja yang menjadi 
kelemahan yang ada pada perusahaan untuk kemudian mengambil tindakan untuk memperbaikinya.dalam usaha meningkatkan kepuasan kepada karyawannya.

\section{Daftar Pustaka}

Anoraga, P. 2000. Psikologi Dalam

Perusahaan. Jakarta. PT. Rineka Cipta.

As'ad, M. 2005. Seri Umum Sumber

Daya Manusia : Psikologi Industri. Yogyakarta Liberty.

Ambar Teguh Sulistiyani, 2003, Manajemen Sumber Daya Manusia, Penerbit Graha Ilmu, Yogyakarta.

Djokosantoso, Moeljono, 2003, Budaya Korporat dan Keunggulan Korporasi, Penerbit Elex Media Komputindo.

Hasibuan, H, 2002, Manajemen Sumber Daya Manusia, Penerbit Bumi Aksara, Jakarta

Jewell \& Siegall. 2002. Psikologi Industry/Organisasi Modern. Edisi 2. (Alih bahasa: Pudjaatmaka). Jakarta: Arcan.

Mangkunegara, Prabu, 2000, Management $\underline{\text { Sumber Daya Manusia Perusahaan, }}$
Penerbit PT. Remaja Rosdakarya, Bandung.

Mangkunegara, A. 1993. Psikologi Perusahaan. Bandung : Triguna Karya.

Manullang, 2007. Manajemen Personalia. Jakarta : Ghalia Indon

Rivai, Veithzal, 2005. Manajemen Sumber Daya Manusia untuk Perusahaan, dari Tori Praktek, Penerbit, Murai Persada, Divisi Buku Pilihan, PT. Raja Grafindo Persada, Jakarta.

Sedarmayanti, 2001, Sumber Daya Manusia dan Produktivitas Kerja, Penerbit CV. Mandar Maju, Bandung.

Santoso, Singgih. 2000, Menggunakan SPSS untuk Statistik Multivariate

Elexmedia Komputindo

Sugiono. 2004 Metodologi Penelitian Bisnis Jakarta. PT. Rineka Cipta. Stephen P. Robbin. 2002. Teori Organisasi. Jakarta: Arcan

Sunarto. 2003. Teori Organisasi. Yogyakarta: Amus\&Mahendro Total Design 
